\title{
PENERAPAN KEBIJAKAN KURIKULUM PAUD DALAM PEMBELAJARAN NILAI AGAMA MORAL
}

\author{
Syarifah Zahra ${ }^{1}$; Nurhayati Djamas ${ }^{1}$ \\ ${ }^{1}$ Program Studi Pendidikan Guru Pendidikan Anak Usia Dini, Fakultas Psikologi dan Pendidikan, \\ Universitas Al-Azhar Indonesia, Jalan Sisingamangaraja, Kebayoran Baru, Jakarta Selatan 12110 \\ Penulis untuk Korespondensi/E-mail:n.djamas@uai.ac.id
}

\begin{abstract}
Abstrak - Penelitian ini bertujuan untuk menjelaskan penerapan kebijakan kurikulum dalam pembelajaran NAM anak usia 5-6 tahun di TK Islam dan di RA Kecamatan P esanggrahan. Metode yang digunakan dalam penelitian ini adalah deskriptif-komparatif dengan pendekatan kualitatif dan teknik pengumpulan data menggunakan observasi, wawancara, dan dokumentasi. Subjek penelitian ini adalah 4 guru dan 4 Kepala Sekolah. Berdasarkan hasil penelitian diketahui bahwa TK Islam dan Raudhatul Athfal menggunakan kebijakan Permendikbud No. 137 dan 146, namun perbedaan yang nampak pada TK Islam dan Raudhatul Athfal yaitu pada pedoman kurikulum, metode dalam penyampaian pembelajaran NAM, media pembelajaran yang digunakan, materi dalam pembelajaran NAM, serta evaluasi akhir terkait pembelajaran NAM. Kesimpulannya bahwa pada penerapan kebijakan pendidikan dalam pembelajaran NAM di TK Islam dan RA memiliki pedoman yang sama, hanya saja kemudian RA mengintergrasikan dengan Keputusan Dirjen PAI Nomor 3489 sehingga menjadi pedoman kurikulum Raudhatul Athfal. Adapun pada segi standar pencapaian,TK Islam berpedoman pada Visi dan Misi yang mereka buat masing-masing, yang kemudian dijadikan standar pencapaian untuk tambahan materi pada pembelajaran NAM, sedangkan RA sudah memiliki standar pencapaian tersendiri khusus untuk pembelajaran NAM yang sudah tercantum dalam pedoman kurikulum RA, begitupun dengan proses pembuatan materi.
\end{abstract}

Kata Kunci: Penerapan Kebijakan Kurikulum, Pembelajaran Nilai Agama dan Moral, TK Islam dan Raudhatul Athfal.

Abstract - This study aims to explain the application of curriculum policies in NAM learning for children aged 5-6 years in Islamic Kindergarten and in RA Pesanggrahan District. The method used in this study is descriptive-comparative with a qualitative approach and data collection techniques using observation, interviews, and documentation. The subjects of this study were 4 teachers and 4 Principals. Based on the results of the study, it is known that Islamic Kindergarten and RaudhatulAthfal use the policy of Minister of Education and Culture No. 137 and 146, but the differences seen in Islamic Kindergarten and Raudhatul Athfal are in curriculum guidelines, methods for delivering NAM learning, learning media used, material in NAM learning, and final evaluation of NAM learning. In conclusion, the application of education policy in NAM learning at Islamic Kindergarten and $R A$ has the same guidelines, only then doeshowever, $R A$ then integrates that policy with the Decree of the Director General of Islamic Education Number 3489 so that it becomes the curriculum guide for RaudhatulAthfal. As for the standard of achievement, Islamic Kindergarten is guided by theitsVision and Mission. that each of them makes, thenwhichbecomes the standard of achievement for additional material in NAM learning, whiles e RA already has its own achievement standards specifically for NAM learning that has been listed in RA curriculum guidelines, as well as the process of making material

Keywords: Application of Curriculum Policy, Learning Value of Religion and Moral, Islamic Kindergarten and RaudhatulAthfal 


\section{PENDAHULUAN}

$\mathrm{P}$ endidikan yang diberikan untuk anak usia dini merupakan upaya peletakan dasar pengembangan pribadi anak. Pelaksanaannya dapat dilakukan di dalam keluarga, sekolah, maupun masyarakat. Sekolah sebagai salah satu lembaga pendidikan harus memperhatikan standar-standar yang mengatur tentang penyelenggaraan layanan pendidikan bagi anak usia dini, yang dinamakan standar Nasional Pendidikan Anak Usia Dini. Standar Nasional merupakan kriteria tentang pengelolaan dan penyelenggaraan PAUD seluruh wilayah hukum kesatuan RI. Terdapat beberapa standar yang harus dipenuhi oleh lembaga PAUD, yaitu 1). standar tingkat pencapaian perkembangan anak usia dini (STPPA); 2). standar isi; 3). standar proses; 4). standar penilaian; 5). standar pendidikan dan tenaga kependidikan; 6). standar sarana dan prasarana; 7). standar pengelolaan; 8). standar pembiayaan.

Salah satu standar PAUD yang harus diperhatikan adalah standar tingkat pencapaian anak usia dini (STPPA). Standar tersebut menjelaskan tentang aspek perkembangan yang dimiliki setiap anak, yaitu Aspek perkembangan moral dan agama, fisik motorik, bahasa, kognitif, sosial emosional, dan seni. Hal ini sesuai dengan pendapat Setiadi (dalam Nurjanah, 2017: 3) bahwa pendidikan anakusia dini merupakan salah satu bentuk penyelenggaraan pendidikan yang menitikberatkan pada peletakkan dasar ke arah pertumbuhan dan perkembangan fisik motorik, kognitif, sosio emosional dan bahasa sesuai dengan tahap perkembangan yang dilalui oleh anak usia dini.

Melihat hal tersebut, dapat dikatakan bahwa pendidikan anak usia dini harus diselenggarakan dengan menyesuaikan pertumbuhan dan aspek perkembangan anak. Oleh sebab itu, pembelajaran yang diselenggarakan oleh lembaga PAUD juga harus menyesuaikan dengan kebutuhan pertumbuhan dan perkembangan anak usia dini, karena pada dasarnya pembelajaran adalah salah satu komponen yang sangat berhubungan erat dengan tingkat pencapaian anak. Di dalam Peraturan Menteri Pendidikan dan Kebudayaan Republik Indonesia Nomor 137 Tahun 2014, tertulis bahwa Pembelajaran adalah proses interaksi antara anak didik dan pendidik dengan melibatkan orang tua serta sumber belajar pada suasana belajar bermain di satuan atau program PAUD.

Sehubungan dengan uraian di atas, maka pendidikan yang diberikan kepada anak usia dini merupakan upaya untuk menciptakan lingkungan yang kondusif dan memberikan yang terbaik bagi perkembangan berbagai potensi peserta didik. Dilihat dari implementasinya, penyelenggaraan PAUD memerlukan dukungan dari berbagai pihak, baik dari pemerintah, masyarakat, maupun orangtua. Oleh karena itu, keberadaan lembaga pendidikan anak usia dini diatur oleh pemerintah melalui Undang-Undang RI nomor 20 tahun 2003 tentang Sistem Pendidikan Nasional yang menyebutkan bahwa setiap penyelenggaraan pendidikan anak usia dini memiliki ciri khusus sesuai dengan jalur pendidikan dimana lembaga tersebut berada.

Di dalam UU RI Nomor 20 tahun 2003 pada Bab VI Pasal 28, tertulis bahwa: (1) Pendidikan anak usia dini diselenggarakan sebelum jenjang pendidikan dasar; (2) Pendidikan anak usia dini dapat diselenggarakan melalui jalur formal, nonformal dan/ atau informal; (3) Pendidikan anak usia dini pada jalur formal berbentuk Taman Kanak-kanak, Raudatul Athfal (RA), ataubentuk lain yang sederajat; (4)Pendidikan anak usia dini pada jalur pendidikan nonformal berbentuk kelompok bermain (KB), taman penitipan anak (TPA), atau bentuk lain yang sederajat; dan (5) Pendidikan anakusiadini pada jalur pendidikan informal berbentuk pendidikan keluarga atau pendidikan yang diselenggarakan olehlingkungan. Adanya kebijakan tersebut menunjukkan dukungan pemerintah terhadap penyelenggaraan PAUD.

\section{Penerapan Kebijakan}

Kebijakan merupakan suatu tindakan yang bermaksud untuk mencapai tujuan tertentu (Heglo dalam Abidin, 2002: 21). Sementara menurut Carl Friedrich (dalam Indiahono, 2009: 18), kebijakan merupakan suatu arah tindakan yang diusulkan oleh seseorang, kelompok atau pemerintah dalam suatu lingkungan tertentu yang memberikan hambatan-hambatan dan kesempatan-kesempatan terhadap kebijakan yang diusulkan untuk menggunakan dan mengatasi dalam rangka mencapai suatu tujuan, 
atau merealisasikan suatu sasaran atau suatu maksud tertentu.

Kebijakan dibuat agar suatu tujuan bisa berjalan secara terarah sesuai dengan keputusan kepemerintahan, dalam hal ini kebijakan yang dibuat disesuaikan dengan kebutuhan masyarakat. Terutama dalam hal pendidikan, banyak kebijakan-kebijakan yang telah dibuat oleh lembaga pendidikan demi tercapainya tujuan pendidikan. Pada lembaga pendidikan anak usia dini contohnya, terdapat dua lembaga yang memiliki kebijakan terkait kurikulum pendidikan anak usia dini. Pendidikan anak usia dini dalam penyelenggaraannya terbagi dalam dua Kementerian, yaitu Kementerian Pendidikan dan Kebudayaan (Kemendikbud) Republik Indonesia untuk pendidikan Taman Kanak-Kanak (anak usia 4-6 tahun) umum dan berbasis agama, sedangkan Kementerian Agama (Kemenag) Republik Indonesia untuk pendidikan Taman Kanak-Kanak (anakusia 4-6 tahun) khusus berbasis agama. TK berbasis agama Islam sendiri di dalam Kementerian Agama Republik Indonesia ada di bawah naungan Direktur Jendral Pendidikan Islam.

Terkait dengan pendidikan anak usia dini, Kementerian Pendidikan dan Kebudayaan mengeluarkan dua peraturan yaitu Permendikbud No. 137 tentang Standar Nasional PAUD dan No. 146 tentang Kurikulum PAUD 2013, sedangkan Kementerian Agama mengeluarkan 1 Keputusan yaitu Keputusan Direktur Jendral Pendidikan Islam Nomor 3489 tentang Kurikulum Raudhatul Athfal. Berikut beberapa kebijakan pendidikan yang dikeluarkan oleh dua Kementerian tersebut:

1. Kebijakan Kementerian Pendidikan dan KebudayaanRepublik Indonesia

a. Peraturan Menteri Pendidikan dan Kebudayaan Republik Indonesia Nomor 137 Tahun 2013, tentang Standar Nasional PAUD.

b. Peraturan Menteri Pendidikan dan Kebudayaan Republik Indonesia Nomor 146 Tahun 2014, tentang Kurikulum 2013 Pendidikan Anak Usia Dini.

2. Kebijakan Kementerian Agama Republik Indonesia

Rujukan pembelajaran berada dalam Keputusan Direktur Jenderal Pendidikan
Islam Nomor 3489 Tahun 2016, tentang Kurikulum Raudhatul Athfal.

\section{Pembelajaran Nilai Agama dan Moral}

Pembelajaran adalah proses interaksi antara pendidik dengan peserta didik melalui kegiatan bermain pada lingkungan belajar yang aman dan menyenangkan dengan menggunakan berbagai sumber belajar (Kemendikbud, 2015: 22). Adapun menurut Mulyasa (2012: 145), pembelajaran merupakan aktualisasi kurikulum yang menuntut aktivitas guru dalam menciptakan dan menumbuhkan kegiatan sesuai dengan rencana yang telah diprogramkan.

Sehubungan dengan pengertian di atas, di dalam Permendikbud Nomor 146 tahun 2014 disebutkan bahwa aspek nilai agama dan moral adalah aspek yang mencakup perwujudan suasana belajar untuk berkembangnya perilaku baik yang bersumber dari nilai agama dan moral serta bersumber dari kehidupan bermasyarakat dalam konteks bermain. Berdasarkan uraian tersebut dapat dikatakan bahwa pembelajaran nilai agama dan moral adalah suatu proses atau usaha untuk mengaktualisasikan kurikulum sebagai bentuk aktivitas untuk mencapai hasil belajar peserta didik yang maksimal dengan pengembangan aturan kehidupan bermasyarakat dan beragama dalam konteks bermain.

\section{Penerapan Kebijakan Terkait Pembelajaran Nilai Agama dan Moral}

Kebijakan pendidikan anak usia dini tertuang dalam Undang-Undang RI No. 20 tahun 2003 tentang Sistem Pendidikan Nasional yang menyebutkan bahwa setiap penyelenggaraan PAUD memiliki ciri khusus sesuai dengan jalur pendidikan dimana lembaga tersebut berada. Terkait dengan kebijakan pendidikan anak usia dini yang berada di dalam Undang-Undang, kemudian lebih dijelaskan melalui Peraturan Pemerintah untuk Kementerian Pendidikan dan Kebudayaan, dan Keputusan untuk Kementerian Agama, dan untuk mengimplementasikan apa yang sudahada di dalam Peraturan Pemerintah atau dalam Keputusan, maka dibuatlah petunjuk teknis untuk pelaksanaannya. 
Tabel 1. Standar Isi Tentang Tingkat Pencapaian Perkembangan Anak (STPPA)

\begin{tabular}{|c|c|}
\hline $\begin{array}{c}\text { Lingkup } \\
\text { Perkembangan }\end{array}$ & $\begin{array}{c}\text { Tingkat Pencapaian } \\
\text { Perkembangan Anak } \\
\text { Usia 5-6 Tahun } \\
\end{array}$ \\
\hline \multirow[t]{6}{*}{$\begin{array}{l}\text { Nilai Agama dan } \\
\text { Moral }\end{array}$} & $\begin{array}{l}\text { 1. Mengenal agama } \\
\text { yang dianut }\end{array}$ \\
\hline & 2. Mengerjakan ibadah \\
\hline & $\begin{array}{l}\text { 3. Berperilaku jujur, } \\
\text { penolong, sopan, } \\
\text { hormat, sportif, dsb. }\end{array}$ \\
\hline & $\begin{array}{l}\text { 4. Menjaga kebersihan } \\
\text { diri dan lingkungan. }\end{array}$ \\
\hline & $\begin{array}{l}\text { 5. Mengetahui hari } \\
\text { besar agama }\end{array}$ \\
\hline & $\begin{array}{l}\text { 6. Menghormati } \\
\text { (toleransi) agama } \\
\text { orang lain }\end{array}$ \\
\hline
\end{tabular}

Adapun petunjuk teknis terkait pembelajaran dibedakan menjadi petunjuk teknis yang dikeluarkan oleh Kementerian Pendidikan dan Budaya, dan oleh Kementerian Agama, bahwa untuk pelaksanaan Permendikbud terdapat pada petunjuk teknis, tetapi untuk pelaksanaan Keputusan Direktur Jendral Pendidikan Islam ada pada lampiran. Berikut petunjuk teknis dan lampiran dari masing-masing kementerian:

1. Petunjuk Teknis Pembelajaran dalam Penyelenggaraan Taman Kanak-Kanak dari Direktorat Pembinaan PAUD dan Jendral PAUD

a. Perencanaan Pembelajaran

Perencanaan pembelajaran telah dijelaskan di dalam Permendikbud No 137 (2015: 9) Bab V Standar Proses Pasal 12 Ayat 1 bahwa Perencanaan pembelajaran dilakukan dengan pendekatan dan model pembelajaran yang sesuai dengan kebutuhan, karakteristik anak, dan budaya lokal. Disebutkan dalam Kemendikbud (2015: 25) bahwa rencana pengelolaan kelas mencakup penataan lingkungan belajar serta pengorganisasian anak dan kelas (dapat di dalam maupun di luar ruangan). Pengelolaan kelas disesuaikan dengan model pembelajaran yang akan digunakan.

Selain itu, di dalam Permendikbud (2015: 12-13) juga dikutip terkait perencanaan pembelajaran di TK yang meliputi:

1) Program Semester.

2) Rencana Pelaksanaan Pembelajaran Mingguan (RPPM)

3) Rencana Pelaksanaan Pembelajaran Harian (RPPH)

Aspek perkembangan nilai agama dan moral ini mencakup perwujudan suasana belajar untuk berkembangnya perilaku baik yang bersumber dari nilai agama dan moral serta bersumber dari kehidupan bermasyarakat dalam konteks bermain (Permendikbud Nomor 146 tahun 2014: 15). Perkembangan nilai agama dan moral anak usia 5-6 tahun terdapat di tabel 1 .

Adapun Aspek perkembangan nilai agama dan moral anak usia 5-6 tahun yang terdapat di dalam Indikator Pencapaian Perkembangan Anak Usia Dini Permendikbud No. 146 Tahun 2014, dapat digambarkan sebagai berikut:

Tabel 2. Indikator Pencapaian Perkembangan Anak Usia Dini

\begin{tabular}{|c|c|}
\hline $\begin{array}{c}\text { Kompetensi } \\
\text { Dasar }\end{array}$ & $\begin{array}{c}\text { Indikator Pencapaian } \\
\text { Perkembangan AnakUsia 5- } \\
6 \text { Tahun }\end{array}$ \\
\hline $\begin{array}{l}1.1 \\
\text { Mempercayai } \\
\text { adanya Tuhan } \\
\text { melalui } \\
\text { ciptaan-Nya } \\
1.2 \\
\text { Menghargai } \\
\text { diri sendiri, } \\
\text { orang lain, } \\
\text { dan } \\
\text { lingkungan } \\
\text { sekitar } \\
\text { sebagai rasa } \\
\text { syukur } \\
\text { kepadaTuhan }\end{array}$ & $\begin{array}{l}\text { Indikator pencapaian } \\
\text { perkembangan anak untuk KD } \\
\text { pada KI Sikap Spiritual dan } \\
\text { KD pada KI Sikap Sosial tidak } \\
\text { dirumuskan secara tersendiri. } \\
\text { Pembelajaran untuk mencapai } \\
\text { KD } \\
\text {-KD ini dilakukan secara tidak } \\
\text { langsung, tetapi melalui } \\
\text { pembelajaran untuk mencapai } \\
\text { KD-KD pada KI Pengetahuan } \\
\text { dan KI Keterampilan, serta } \\
\text { melalui pembiasaan dan } \\
\text { keteladanan. Dengan kata lain, } \\
\text { sikap positif anak akan } \\
\text { terbentuk ketika dia memiliki } \\
\text { pengetahuan dan mewujudkan } \\
\text { pengetahuan itu dalam bentuk } \\
\text { hasil karya dan/ atau unjuk } \\
\text { kerja. Contoh sikap positif itu } \\
\text { adalah perilaku hidup sehat, } \\
\text { jujur, tanggungjawab, peduli, } \\
\text { kreatif, kritis, percayadiri, } \\
\text { disiplin, mandiri, mampu } \\
\text { bekerjasama, anam mampu } \\
\text { menyesuaikan diri, dan santun. }\end{array}$ \\
\hline
\end{tabular}


b. Pelaksanaan Pembelajaran

Pelaksanaan pembelajaran dijelaskan di dalam Permendikbud No. 137 (2015: 10) Bab V Standar Proses Pasal 13 Ayat 1 bahwa pelaksanaan pembelajaran dilakukan melalui bermain secara interaktif, inspiratif, menyenangkan, kontekstual, dan berpusat pada anak untuk berpartisipasi aktif serta memberikan keleluasaan bagi prakarsa, kreativitas, dan kemandirian sesuai dengan bakat, minat, dan perkembanganfisik serta psikologis anak. Pelaksanan pembelajaran menggunakan kurikulum 2013, salah satu pendekatan pembelajaran yang digunakan dalam kurikulum 2013 adalah pendekatan tematik terpadu.

Model pembelajaran tematik terpadu di TK, kegiatan-kegiatan yang dilakukan untuk satu tema, sub tema, atau sub-sub tema dirancang untuk mencapai secara bersamasama kompetensi sikap, pengetahuan, dan keterampilan dengan mencakup sebagian atau seluruh lingkup pengembangan. Pembelajaran tematik terpadu dilaksanakan dalam tahapan kegiatan pembukaan, inti dan penutup. (Kemendikbud, 2015: 23-26)

c. Evaluasi Pembelajaran

Evaluasi pembelajaran dijelaskan di dalam Permendikbud No 137 (2015: 11) Bab V Standar Proses Pasal 16 Ayat 1-3 bahwa (1) Evaluasi pembelajaran mencakup evaluasi proses dan hasil pembelajaran yang dilakukan oleh pendidik untuk menilai keterlaksanaan rencana pembelajaran (2) Evaluasi hasil pembelajaran dilaksanakan oleh pendidik dengan membandingkan antara rencana dan hasil pembelajaran (3) Hasil evaluasi sebagai dasar pertimbangan tindak lanjut pelaksanaan pengembangan selanjutnya.

Selain itu, yang tercantum pada Depdiknas (2012) (dalam Sutarman, 2016: 109) teknik penilaian pembelajaran pada pendidikan anak usia dini, termasuk anak usia 5-6 tahun dapat diterapkan sebagai berikut: observasi, catatan anekdot, percakapan, penugasan (project), unjuk kerja (performance), dan hasil karya (product).

2. Lampiran Pembelajaran dari Keputusan Direktur Jenderal Pendidikan Islam Nomor 348 Tahun 2016 Tentang Kurikulum RA a. Perencanaan Pembelajaran

Rencana pelaksanaan pembelajaran merupakan rancangan bagi guru RA untuk melaksanakan kegiatan bermain yang memfasilitasi anak dalam proses belajar (Dept. Pendidikan IGRA, 2016: 36). Lembaga Raudhatul Athfal menetapkan perencanaan menggunakan kebijakan yang sudah ada di dalam Kurikulum Raudhatul Athfal. Kurikulum tersebut dibuat berdasarkan Permendikbud No 137 dan No 146 , yang kemudian diintegrasikan dengan nilai-nilai pendidikan agama Islam dari Kementerian Agama melalui Keputusan Direktur Jenderal Pendidikan Islam Nomor 3489 Tahun 2016, tentang Kurikulum Raudhatul Athfal.

Kurikulum tersebut tetap berpedoman pada Kurikulum 2013 dengan pendekatan tematik terpadu, melakukan penyusunan dimulai dari Program Tahunan, Program Semester, RPPM, sampai dengan RPPH. Adapun pengembangan rencana kegiatan pembelajaran yang tercantum di dalam Departemen Pendidikan IGRA (2016: 37-

38) adalah sebagai berikut:

1) Terdapat Program Semester

2) Terdapat Pelaksanaan Pembelajaran Mingguan

3) Terdapat Pelaksanaan Pembelajaran Harian

Selain itu, nilai pendidikan agama Islam sendiri memiliki beberapa materi tambahan. Berikut contoh materi yang terdapat dalam Keputusan Direktur Jenderal Pendidikan Islam Nomor 3489 Tahun 2016, tentang Kurikulum Raudhatul Athfal:

1) Materi Al-Qur'an dan Hadist Kelompok A dan B

a) Hafalan surah-surah pendek

b) Hafalan hadist-hadist

c) Hafalan kutipan ayat-ayat AlQur'an

d) Do'a harian

e) Dzikir harian (baik berupa asmaul husna maupun kalimat Thayyibah)

2) Materi Pendidikan Agama Islam (PAI)
a) Rukun Iman
b) Rukun Islam
c) Ihsan
d) Kisah nabi dan rasul
e) Lagu-lagu Islami 
Materi tersebut diistilahkan dengan nama:

1) Dawaamul Qur'an: Berisi surah surah pendek yang dikenalkan dan dibaca secara kontinyu dalam kegiatan seharihari.

2) Mutiara Alqur'an: kutipan ayat al Qur'an yang utuh atau penggalan ayat yang mengandung hikmah dalam kegiatan sehari-hari.

3) Mutiara Hadis: Kutipan Hadis yang mengandung hikmah dalam kehidupan sehari-hari,

4) Doa Harian: Doa yang dikenalkan sesuai dengan kegiatan harian yang dibaca sehari-hari.

5) Dzikir Harian: Kalimat-kalimat thayyibah yang digunakan sehari-hari sesuai situasi dan kondisi,

6) Asmaul Husna: 99 nama Allah yang dikenalkan baik melalui senandung maupun aplikasi dalam kehidupan sehari-hari sesuai kondisi dan situasi.

b. Pelaksanaan Pembelajaran

Sama halnya dengan perencanaan, pelaksanaan juga dilaksanakan sesuai dengan perencaaan yang dibuat dengan kurikulum yang sudah diintegrasikan yaitu kurikulum Raudhatul Athfal. Tidak ada penjelasan yang spesifik mengenai kegiatan pembuka, inti dan penutup, begitupun juga dengan metode dan media yang harus digunakan.

c. Evaluasi Pembelajaran

Dalam setiap proses pembelajaran tentunya terdapat evaluasi atau penilaian di dalamnya. RA sendiri sudah memiliki petunjuk teknis penilaian pembelajaran siswa RA yang terdapat di dalam Keputusan Direktur Jenderal Pendidikan Islam Nomor 5611 Tahun 2016.

Berdasarkan hasil wawancara dengan Kepala Sekolah dan observasi awal di kelas B yang dilakukan pada bulan Maret-April tahun 2018 di salah satu TK Islam dan RA di daerah Pesanggrahan. Untuk RA sendiri terdapat 2 pedoman yang dilaksanakan dalam pembelajarannya, satu pedoman dari Direktorat PAUD dan satu pedoman dari Kementrian Agama. Lain halnya dengan TK Islam yang hanya mengikuti pedoman dari Direktorat PAUD dalam implementasi pembelajarannya. Selain itu salah satu RA tersebut juga melaksanakan kegiatan pembelajaran dengan adanya kegiatan-kegiatan keagamaan yang ditambahkan seperti tadarus, shalat dhuha, pengenalan bahasa Arab dan lain sebagainya, sedangkan salah satu TK Islam mengikuti alur kegiatan TK pada umumnya. Namun untuk pembiasaan sikap semua lembaga melakukannya hanya berbeda pada metode penerapannya.

Adapun tujuan penelitian ini untuk mendeskripsikan penerapan kebijakan kurikulum dalam pembelajaran nilai agama dan moral anak usia 5-6 tahun di TK Islam dan di Raudhatul Athfal Kecamatan Pesanggrahan.

\section{METODE PENELITIAN}

Metode yang digunakan dalam penelitian ini adalah metode deskriptif-komparatif dengan pendekatan kualitatif. Menurut Moleong (2001: 6), penelitian desktiptif adalah penelitian dengan data yang dikumpulkan berupa katakata, gambar dan bukan angka-angka. Adapun penelitian komparatif menurut Sugiyono (2014: 54) adalah penelitian yang membandingkan keadaan satu variable atau lebih pada dua atau lebih sampel yang berbeda, atau dua waktu yang berbeda. Penelitian ini dilakukan sejak bulan Januari sampai bulan Oktober 2018.

Sumber data yang digunakan adalah data primer dan data skunder. Pada penelitian ini data primer didapat dari hasil wawancara dan observasi dengan guru kelas B. Selain itu data juga diperkuat dengan mewawancarai Kepala Sekolah dan salah satu orang tua peserta didik kelas B. Untuk melengkapi data primer, digunakan data sekunder berupa dokumentasi kegiatan dan berkas-berkas tertulis berupa perencanaan, pelaksanaan sampai evaluasi pembelajaran di kelas B. Teknik pengumpulan data yang dilakukan dengan menggunakan wawancara, observasi dan dokumentasi akan diuji keabsahannya dengan menggunakan triangulasi teknik.

\section{HASIL DAN PEMBAHASAN}

\section{Kebijakan Pemerintah}

TK Islam dan Raudhatul Athfal menggunakan kebijakan Permendikbud RI No. 137 Tahun 2014, tentang Standar PAUD dan Permendikbud RI No.146 Tahun 2014, tentang Kurikulum 2013 PAUD. Hal ini dikarenakan 
kebijakan tersebut memang sudah menjadi ketetapan yang harus digunakan untuk pembelajaran anak usia dini salah satunya di Taman Kanak-Kanak.

Begitupun dengan Raudhatul Athfal, lembaga tersebut tetap menggunakan kebijakan yang sama dengan TK Islam yaitu Permendikbud RI No. 137 Tahun 2014, tentang Standar PAUD dan Permendikbud RI No.146 Tahun 2014, tentang Kurikulum 2013PAUD, namun RA juga memiliki kebijakan tersendiri yang dibuat berdasarkan Keputusan Direktur Jenderal PAI No. 3489 tahun 2016, yang kemudian kedua kebijakan tersebut diintegrasikan menjadi kurikulum Raudhatul Athfal.

\section{Kebijakan Sekolah}

Tidak hanya kebijakan dari pemerintah, pada umumnya sekolah juga memiliki kebijakan tersendiri dengan membuat kurikulum tersendiri untuk standar pencapaian peserta didik di sekolah. Terbukti dari hasil wawancara, observasi dan dokumentasi dengan TK Islam 1 dan 2 serta RA 1 dan 2, dari keempat lembaga tersebut yang memiliki kebijakan sekolah dengan bentuk pedoman kurikulum hanya TK Islam 2 dan RA 2. Kebijakan tersebut dibuat guna untuk mempermudah guru dalam penyusunan perencanaan pembelajaran. Selain itu, sekolah juga dapat memiliki standar pencapaian tersendiri namun tetap pada ketentuan pemerintah.

TK Islam 2 memiliki kebijakan sendiri yang diberi nama Buku Pedoman Kurikulum TK Islam 2. Kebijakan tersebut dibuat berdasarkan pada kebijakan pemerintah dalam Peraturan Mentri Pendidikan dan Kebudayaan Nomor 146 tentang Kurikulum 2013 PAUD dan Nomor 137 tentang Standar PAUD, yang kemudian dikembangkan dan ditambahkan poin-poin dari aspek perkembangannya terutama pada aspek perkembangan nilai agama dan moral. Kebijakan tersebut dibuat untuk mempermudah guru dalam menyusun program tahunan sampai dengan RPPH. Tidak ada kebijakan sekolah yang dibuat oleh Raudhatul Athfal 1. Hal ini dikarenakan sekolah hanya mengikuti dan mengembangkan keseluruhan rangkaian pembelajaran dari pedoman kurikulum Raudhatul Athfal.
Sama halnya dengan TK Islam 2, dalam hal ini Raudhatul Athfal 2 memiliki kebijakan sekolah berbentuk Buku Pedoman Raudhatul Athfal 2. Kebijakan tersebut dikembangkan melalui pedoman kurikulum Raudhatul Athfal dan dibuat guna untuk mempermudah guru dalam membuat perencanaan program tahunan sampai dengan RPPH. Selain itu, juga agar sekolah punya acuan dan standar tersendiri.

Hal ini sesuai dengan yang tercatat di dalam Kemendikbud (2015: 1) bahwa kebijakan atau petunjuk teknis dibuat guna memberikan acuan kepada masyarakat. Selain itu juga dapat dijadikan sebagai standar acuan bagi penyelenggara TK dalam memberikan pelayanan pendidikan.

\section{Penerapan Kebijakan}

\section{Perencanaan Pembelajaran}

Beberapa Raudhatul Athfal menggunakan model pembelajaran sentra, termasuk RA 1 dan RA 2. Guru memilih model pembelajaran tersebut dikarenakan pembelajaran di sentra tidak monoton, pembelajaran lebih spesifik ke tema yang sedang digunakan dan lebih bervariasi, anak dapat mengenal guru-guru yang lain, adanya suasana yang baru dan lain sebagainya. Lain halnya dengan TK Islam 1 dan 2 yang menggunakan model kelas kelompok. Guru memilih model kelompok dikarenakan lebih mudah penerapannya.

Adapun perencanaan program tahunan, program semester, perencanaan pembelajaran mingguan, sampa dengan perencanaan pembelajaran harian, keempat lembaga tersebut yaitu TK Islaml dan 2 serta RA 1 dan 2 memiliki cara penyusunan perencanaan yang sama, dan penambahan materi pada pembelajaran nilai agama dan moral yang sama, yaitu terdapat surat-surat pendek, hadis-hadis, doa harian, asmaul husna, praktek shalat, praktek berwudhu, dan lain sebagainya. Hal yang membedakan hanya pada ketetapan yang ada dalam kebijakan. Jika TK Islam membuat penambahan materi pada nilai agama dan moral dengan pembuatan sendiri yaitu berdasarkan implementasi dari visi misi yang dibuat oleh sekolah dan di luar dari kebijakan Permendikbud No. 146 dan No.137, namun Raudhatul Athfal membuat materi tambahan pada nilai agama dan moral sesuai dengan 
ketentuan yang sudah dibuat dalam pedoman kurikulum Raudhatul Athfal.

TK Islam 1 dan 2 serta RA 1 dan 2 mengggunakan model pembelajaran yang berbeda, TK Islam 1 dan 2 sama-sama menggunakan model pembelajaran kelompok dikarenakan lebih mudah dan memang belum ada ilmu untuk menerapkan sentra. RA 1 dan 2 sama-sama menggunakan model pembelajaran sentra dikarenakan anak dapat mengenal suasana baru dan pembelajaran lebih luas. Sesuai dengan pendapat Mulyasa (2012: 148) model pembelajaran yang biasa dilakukan pada satuan pendidikan anak usia dini adalah pembelajaran klasikal, pembelajarankelompok dengan kegiatan pengaman, pembelajaran berbasis sudut kegiatan, pembelajaran area, dan pembelajaran berbasis sentra. Untuk perencanaan dari program semester sampai dengan RPPH keduanya memiliki perencanaan yang sama.

\section{Pelaksanaan Pembelajaran}

TK Islam 1 dan 2 serta Raudhatul Athfal 1 dan 2 terkait pelaksanaan kegiatan pembuka, kegiatan inti, sampai dengan kegiatan penutup memiliki kegiatan yang sama. Untuk pembelajaran nilai agama dan moral sama-sama terdapat pembacaan iqro yang disisipkan di dalam kegiatan pembelajaran. Sama-sama membaca doa sebelum dan sesudah melakukan kegiatan. Sama-sama terdapat pembiasaan praktek shalat dan wudhu setiap minggunya dan lain sebagainya. Namun untuk pembiasaan sikap dan perilaku yang baik dan benar tergantung pada penerapan masing-masing guru kelas.

Pelaksanaan pembelajaran tentunya terdapat materi, metode, media yang digunakan dalam pembalajaran, termasuk dalam pembelajaran nilai agama dan moral. Materi dalam pembelajaran nilai agama dan moral di TK Islam 1 dan 2 serta RA 1 dan 2 memiliki materi yang hampir sama, seperti doa harian, suratsurat pendek, potongan ayat suci Al-Qur'an, hadist-hadist, asmaul husna bacaan shalat dan sebagainya. Namun seperti yang sudah dijelaskan pada paragraph sebelumnya bahwa TK Islam membuat materi tambahan pada pembelajaran nilai agama dan moral dengan ketentuan sekolah masing-masing. Berbeda dengan RA yang membuat materi pembelajaran nilai agama dan moral tambahan dengan mengikuti ketentuan yang terdapat di dalam pedoman kurikulum Raudhatul Athfal.

Lain halnya dengan materi, metode dalam pembelajaran nilai agama dan moral tentunya diterapkan oleh masing-masing guru dengan cara yang berbeda. Untuk TK Islam 1 dari hasil wawancara dengan guru kelas $\mathrm{B}$, bahwa metode yang sering digunakan dalam pembelajaran nilai agama dan moral adalah metode langsung seperti bercakap-cakap dan Tanya jawab, metode ini menurutnya InsyaAllah sudah tepat asalkan tidak lupa untuk selalu diucapkan, dipraktekkan dan dibiasakan. Selain itu guru juga memiliki strategi agar anak selalu mengingat pembelajaran nilai agama dan moral tersebut seperti contohnya mengingatkan sebelum pulang dan saat datang ke sekolah apakah sudah dipraktekkan ucapan salamnya dan bersalaman dengan ayah bunda.

Berbeda dengan TK Islam 1, TK Islam 2 memiliki metode yang berbeda dalam pembelajaran nilai agama dan moral. Metode yang sering digunakan dalam pembelajaran nilai agama dan moral dari hasil wawancara dan observasi dengan guru kelas B adalah metode demonstrasi dan bernyanyi. Metode ini menurutnya sudah sangat efektif karena dengan demonstrasi anak dapat berpikir, sedangkan metode bernyanyi dapat mengambil fokus dan perhatian anak. Selain metode, guru juga memiliki strategi yaitu dengan tepukan dan gerakan untuk penyampaian pembelajaran nilai agama dan moral.

Begitu pun dengan RA 1 yang menggunakan berbagai macam metode dalam pembelajaran nilai agama dan moral. Beberapa metode yang digunakan dari hasil wawancara dengan guru kelas B diantaranya metode bercerita, praktek langsung, demonstrasi, tanya jawab dan sebagainya. Menurut beliau menggunakan metode tersebut dikarenakan mudah dipahami oleh anak, mudah tersampaikan dan anak dapat mengikuti dengan baik. Adapun strategi yang digunakan oleh guru yaitu dengancara mencontohkan ke anak terlebih dahulu, selain itu juga sekolah mendatangkan guru laki-laki dari luar sekolah khusus untuk pembelajaran nilai agama dan moral agar anak merasakan hal yang berbeda dalam penyampaiannya. 
Metode-metode tersebut yang sering digunakan oleh guru-guru di TK Islam 1 dan 2 serta RA 1 dan 2 diantaranya adalah metode bercerita, bernyanyi, demonstrasi, bercakap-cakap, gerakan, tepukan dan sebagainya. Sesuai dengan yang tercantum di dalam Kemendikbud (2015: 27-29) bahwa metode pembelajaran dirancang dalam kegiatan bermain yang bermakna dan menyenangkan bagi anak, dan metode yang dianggap sesuai untuk TK diantaranya adalah bercerita, demontrasi, bercakap-cakap, pemberian tugas, sosio-drama/ bermain peran, karyawisata, proyek, dan eksperimen.

Selain itu metode yang banyak dilakukan dalam pembelajaarn nilai agama dan moral adalah praktik langsung. Dimana metode ini dianggap paling mudah untuk diterapkan kepada anak karena anak langsung memperagakan dan sulit jika hanya dihafal tanpa anak memperagakan. Sesuai dengan pendapat Sujiyono (2010: 122) bahwa melalui praktik langsung diharapkan anak akan dapat pengalaman melalui interaksi langsung dengan objek.

Adapun RA 2 dalam pembelajaran nilai agama dan moral dari hasil wawancara dengan guru kelas B yaitu menggunakan metode bernyanyi, bercerita, dan disesuaikan dengan anak. Menggunakan metode tersebut dikarenakan anak-anak menyukai hal-hal yang menyenangkan. Selain metode, guru juga memiliki strategi yang digunakannya itu dengan pendekatan ke anak dengan merangkul, bahasa tubuh yang ekspresif dan mengajak, serta tidak lupa dengan pujian di setiap perilaku baik atau pencapaian yang baik.

Selain materi dan metode, dalam pelaksanaan juga dilihat media apa yang digunakan dalam penyampaian pembelajaran nilai agama dan moral. TK Islam 1 biasanyamenggunakan media puzzle, gambar atau poster terkait agama, dengan media tersebut anak lebih mudah mengerti karena terdapat gambar-gambar. Adapundengan TK Islam 2 yaitu menggunakan media buku cerita, wayang, dan sebagainya. Menggunakan media tersebut karena dapat menarik perhatian anak dengan adanya gambar yang bergerak.

Selain itu, dalam pembelajaran nilai agama dan moral, RA 1 menggunakan media gambar, boneka tangan, poster-poster rukun Iman dan
Islam, dan LCD proyektor untuk cerita sejarah Nabi-Nabi dan sebagainya. Memilih media tersebut dikarenakan untuk yang berbentuk gambar-gambar mudah dilihat dan untuk boneka tangan lebih menarik perhatian anak dengan adanya gerakan-gerakan. Sedangkan RA 2 dalam pembelajaran nilai agama dan moral hanya menggunakan media buku cerita dan buku-buku pengenalan agama lainnya. Hal ini dikarenakan anak-anak lebih tertarik dengan gambar-gambar dan sarana memang belum memadai untuk media 3 dimensi.

\section{Evaluasi Pembelajaran}

Adapun penjelasan mengenai teknik evaluasi dalam pembelajaran nilai agama dan moral yang digunakan dari hasil observasi yang peniliti lakukan di TK Islam 1 dan 2 serta RA 1 dan 2 adalah sama-sama sering menggunakan teknik evaluasi penggunaan observasi, catatan anekdot, percakapan, penugasan, unjukkerja dan hasil karya, namun untuk hasil karya sangat jarang digunakan di empat lembaga tersebut karena lebih banyak menggunakan metode praktek langsung seperti praktek shalat, wudhu, membaca iqro, menghafal surat-surat pendek, doa harian dan sebagainya. Alat yang digunakan dalam evaluasi juga biasa dibantu dengan berbagai macam alat. TK Islam 1 menggunakan stiker, TK Islam 2 menggunakan spidol yang diberikan ditangan atau di buku peserta didik, RA 1 menggunakan stempel bintang di buku dan stiker bintang dari origami di lemari peserta didik, RA 2 menggunakan bintang pada buku.

Pada evaluasi harian, mingguan, bulanan dan semester, sekolah memiliki format tersediri, kecuali RA. RA dalam pembuatan evaluasi harian, mingguan, bulanan dan semester memiliki format yang sama pada setiap RA dan khusus di RA evaluasi akhir semester tidak hanya berbentuk raport, namun sebelum pembagian raport terdapat tes akhir semester pada pembelajaran nilai agama dan moral yang berbentuk setor hafalan dan praktekshalat. Laporan perkembangan anak yang dibuat oleh keempat lembaga dilakukan pada akhir semester dengan bentuk diskusi dan pembagian raport kepada orang tua dan kepala sekolah.

Evaluasi pada setiap lembaga sama, menggunakan penugasan, unjuk kerja dan sebagainya. Namun untuk RA memiliki tes 
akhir semester untuk melihat pencapaian anak dalam pembelajaran nilai agama dan moral. Sesuai yang tercantum pada Depdiknas (2012) (dalam Sutarman, 2016: 109) penilaian pembelajaran pada pendidikan anak usia dini, termasuk anak usia 5-6 tahun dapat diterapkan sebagai berikut: observasi, catatan anekdot, percakapan, penugasan (project), unjuk kerja (performance), dan hasil karya (product).

\section{SIMPULAN DAN SARAN}

Berdasarkan hasil penelitian yang telah dilakukan bahwa pada penerapan kebijakan pendidikan dalam pembelajaran NAM di TK Islam dan RA memiliki pedoman yang sama, hanya saja kemudian RA mengintergrasikan dengan Keputusan Dirjen PAI Nomor 3489 sehingga menjadi pedoman kurikulum Raudhatul Athfal. Adapun pada segi standar pencapaian, TK Islam berpedoman pada Visi dan Misi yang masing-masing mereka buat, kemudian dijadikan standar pencapaian untuk tambahan materi pada pembelajaran NAM, sedangkan RA sudah memiliki standar pencapaian tersendiri khusus untuk pembelajaran NAM yang sudah tercantum dalam pedoman kurikulum RA. Begitupun dengan proses pembuatan materi, untuk TK Islam dari visi dan misi tersebut maka terdapat penambahan materi dan kegiatan-kegiatan operasional pada pembelajaran nilai agama dan moral, sedangkan RA mengikuti dari pedoman kurikulum Raudhatul Athfal yang sudah ada.

Adapun saran dalam penelitian ini adalah perlunya dilakukan penelitian lanjutan dengan mengembangkan aspek-aspek yang belum terjangkau atau belum menjadi fokus penelitian. Bagi sekolah, diharapkan dapat menjadi bahan evaluasi peningkatan pembelajaran selanjutnya. Bagi pemerintah, diharapkan dapat mengoptimalkan dan memberikan ketentuan yang sama terhadap seluruh lembaga PAUD khususnya TK Islam dan Raudhatul Athfal dalam penerapan pembelajaran pada aspek perkembangan nilai agama dan moral.

\section{DAFTAR PUSTAKA}

Abidin, S.Z (2002). Kebijakan publik. Jakarta: Yayasan Pancur Siwah.

Departemen Pendidikan Pimpinan Pusat IGRA. (2016). Pedoman kurikulum Raudhatul Athfal. Jakarta.

Direktorat Pembinaan PAUD, Direktorat Jenderal PAUD, dan Pendidikan Masyarakat Kementerian Pendidikan dan Kebudayaan. (2015). Petunjuk teknis penyeleggaraan taman kanak-kanak. Jakarta.

Keputusan Direktur Jenderal Pendidikann Islam Nomor 3489 Tahun 2016 tentang Kurikulum Raudhatul Athfal.

Moleong, L.J. (2001). Metodologi penelitian kualitatif. Bandung: PT Remaja Rosdakarya.

Mulyasa, H.E. (2012). Manajemen PAUD. Bandung: PT Remaja Rosdakarya.

Peraturan Mentri Pendidikan dan Kebudayaan RI Nomor 137 Tahun 2014 tentang standar nasional pendidikan anak usia dini.

Peraturan Menteri Pendidikan dan Kebudayaan RI Nomor 146 Tahun 2014 tentang kurikulum 2013 pendidikan anakusia dini.

Sugiyono. (2014). Metode penelitian kuantitatif, kualitatif dan $R \& D$. Bandung: Alfabeta.

Sujiyono, Y.N. (2010). Konsep dasar pendidikan anak usia dini. Jakarta: Indeks. 